\title{
THE ROLE OF PRODUCT-RELATED SERVICES IN SERBIAN MANUFACTURING INDUSTRY
}

\author{
Slavko Rakic \\ University of Novi Sad, Faculty of Technical Sciences, Trg Dositeja Obradovica 6, Novi Sad, \\ slavkorakic@uns.ac.rs
}

\author{
Keywords: servitization, product-related services, manufacturing industry
}

\begin{abstract}
:
Service innovations represent one of the most important sources of competitive advantages for the manufacturing sector in the era of Industry 4.0. Servitization, a new fundamental paradigm in Industry 4.0 is important issue for manufacturing firms when they want to upgrade their productivity, improve the quality of supply and retain competitiveness. Analysis of product-related services (PRS) in Serbia became particularly important in the situation where the Serbian transitional economy opted to alter its growth model. This paper analyses the results of the European Manufacturing Survey (EMS) conducted in manufacturing industries in the Republic of Serbia. The current Serbian dataset of 2018 includes 230 observations of Serbian firms of all manufacturing industries. The empirical results indicate the role of PRS in the period of the transformation of product-oriented firms towards serviceoriented firms.
\end{abstract}

\section{INTRODUCTION}

The servitization trend depicts the relationship between product and service in order to offers fuller market packages and create added value for customers [1]. Recently, service maintenance contracts are increasingly used when industry manufacturers change their business models from product makers to product-as-a-service providers [2]. Hence, prior research highlights the move of some manufacturing industries to offer product-service systems (PSS) [3]. PSS represents a range of services that enable customers to obtain maximum value from their products and increase their loyalty to the manufacturing firm [4]. PSS provides more specific PSS types, one of which is product-related service (PRS), this type of provider not only sells a product, but also offers services that are needed during the use phase of the product [5]. Furthermore, the role of PRS in transformation of manufacturing is not sufficiently investigated in transitional economies [6]. This paper investigates and offers an understanding of the role of PRS in manufacturing firms in transitional economies ot the example of manufacturing sector of the Republic of Serbia.

The remainder of the paper is structured as follows: Section 2 presents the literature review. In Section 3, we present data and research methodology. Section 4 provides research results and discussion. Finally, Section 5 shows the conclusion of this paper with identified limitations of the study and suggestions for further research.

\section{LITERATURE REVIEW}

The importance of services to the overall success of manufacturing firms is growing significantly due to increasing global competition [7]. $60 \%$ of all manufacturing firms from western countries 
Slavko Rakic - The role of product-related services in Serbian manufacturing industry offer integrated products-services in their packets [8]. PRS can be related to different manufacturing industries and present different characteristics and added value for the customers [7]. Some examples of such services are installation, training, operation, repair, maintenance, upgrades, etc [7]. Tukker [5] in his study presents the process of the transformation of product-oriented firms towards service-oriented firms until PRS presents the important thing in the first phase of transformation.

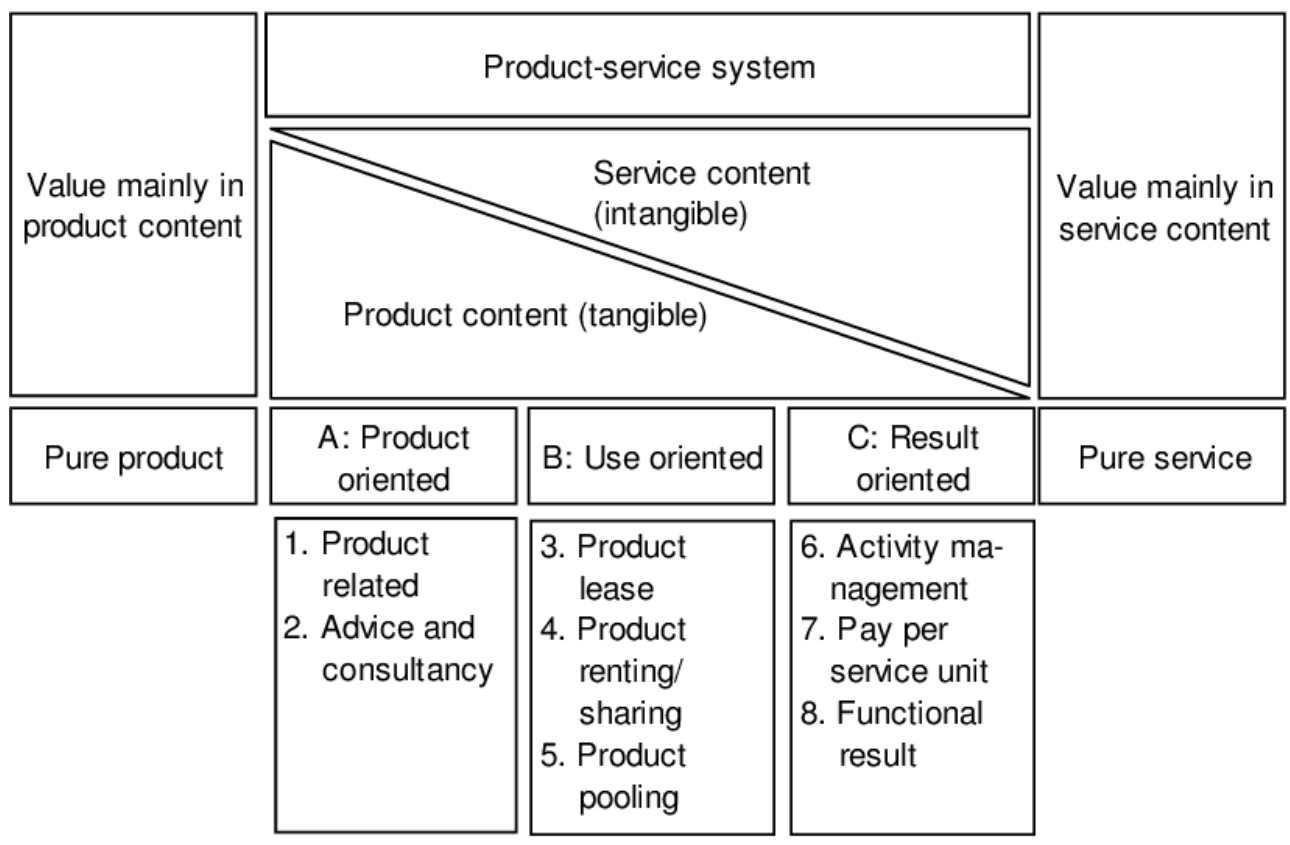

Figure 1 - Position of product-related services in transformation of manufacturing industry [5]

Prior study presents that implementing of product-related services is very complex in manufacturing industries [9]. Moreover, an previous study provides the evidence base underpinning PRS adoption. This research shows that diversification impacts between revenues from products and revenue from services are typically split 50/50 and enables overall business growth [10]. In developed economies, there is considerable debate about the terminology, ideas, and concepts which describe and differentiate products and services in manufacturing firms, but in transitional economies this topic is not sufficiently investigated [6]. Prior studies show the positive effect of PRS on the manufacturing firm performance in developed economies [11]-[12]. Based on these findings authors proposed two research questions:

- $\quad$ RQ1: Which manufacturing industry uses the most number of PRS?

- RQ2: Which PRS is most used by manufacturing firms?

\section{METHODOLOGY}

The survey was conducted under the international project EMS which was coordinated by Fraunhofer ISI Institute from Germany. The dataset used in this paper was built from 2018 data collection. Manufacturing companies (NACE Rev 2 codes from 10 to 33) having at least 20 employees in Serbia were considered, taking into account 230 responses in total. Table 1 presents the classification of manufacturing sectors according to share in the total sample. 
Slavko Rakic - The role of product-related services in Serbian manufacturing industry Table 1: Classification of manufacturing sectors according to share in the total sample

\begin{tabular}{||c|c|c||}
\hline NACE Rev. 2 & $\begin{array}{c}\text { Manufacturing } \\
\text { industry }\end{array}$ & $\begin{array}{c}\text { Share in total } \\
\text { sample (\%) }\end{array}$ \\
\hline \hline 10 & $\begin{array}{c}\text { Manufacture of } \\
\text { food products }\end{array}$ & 17.2 \\
\hline 25 & $\begin{array}{c}\text { Manufacture of } \\
\text { fabricted metals } \\
\text { products, expect } \\
\text { machinery and } \\
\text { equipment }\end{array}$ & 13.2 \\
\hline 22 & $\begin{array}{c}\text { Manufacture of } \\
\text { rubber and plastic } \\
\text { products }\end{array}$ & 9.3 \\
\hline 28 & $\begin{array}{c}\text { Manufacture of } \\
\text { machinery and } \\
\text { equipment n.e.c. }\end{array}$ & 6.6 \\
\hline 27 & $\begin{array}{c}\text { Manufacture of } \\
\text { electrical } \\
\text { equipment }\end{array}$ & 6.6 \\
\hline 14 & $\begin{array}{c}\text { Manufacture of } \\
\text { wearing apparel }\end{array}$ & 5.8 \\
\hline & Other industries & 41.3 \\
\hline
\end{tabular}

To analyze the role of PRS in the manufacturing sector of Serbia, the author employed in-depth descriptive analyses. With all of this information, the author presented which PRS are the most used in manufacturing industries in Serbia. Moreover, he will presented which manufacturing industries used the highest percent of PRS.

\section{RESULTS AND DISCUSSION}

The results of the research were analyzed using the in-depth descriptive statistic. According to RQ1, Table 2 depicts how many PRS are used per firm in all manufacturing industry.

Table 1: Product-related services per firm in the manufacturing industry

\begin{tabular}{|c|c|}
\hline Manufacturing industry & $\begin{array}{c}\text { Number of PRS } \\
\text { per one firm }\end{array}$ \\
\hline \hline Manufacture of other transport equipment & 4 \\
\hline $\begin{array}{c}\text { Manufacture of machinery and equipment } \\
\text { n.e.c. }\end{array}$ & 3.5 \\
\hline $\begin{array}{c}\text { Manufacture of computer, electronic and } \\
\text { optical products }\end{array}$ & 3.3 \\
\hline Manufacture of electrical equipment & 3 \\
\hline $\begin{array}{c}\text { Manufacture of printing and reproduction } \\
\text { of recorded media }\end{array}$ & 2.75 \\
\hline Manufacture of motor vechiles & 2.6 \\
\hline $\begin{array}{c}\text { Manufacture of fabricted metals products, } \\
\text { expect machinery and equipment }\end{array}$ & 2.4 \\
\hline
\end{tabular}

Results presented that Manufacture of other transport equipment use the most PRS - 4, followed by Manufacture of machinery and equipment n.e.c., Manufacture of computer, electronic and 
Slavko Rakic - The role of product-related services in Serbian manufacturing industry optical products, Manufacture of electrical equipment between 3-4 PRS, and Manufacture of printing and reproduction of recorded media, Manufacture of motor vechiles, Manufacture of fabricted metals products, expect machinery and equipment between 2-3 PRS, other industry are under 2 PRS per firm. Moreover, it' important to note that Manufacture of machinery and equipment n.e.c., Manufacture of electrical equipment and Manufacture of fabricted metals products, expect machinery and equipment are in the top five in the share of total sample. According to RQ2, Figure 2 depicts which PRS is most used by manufacturing firms.

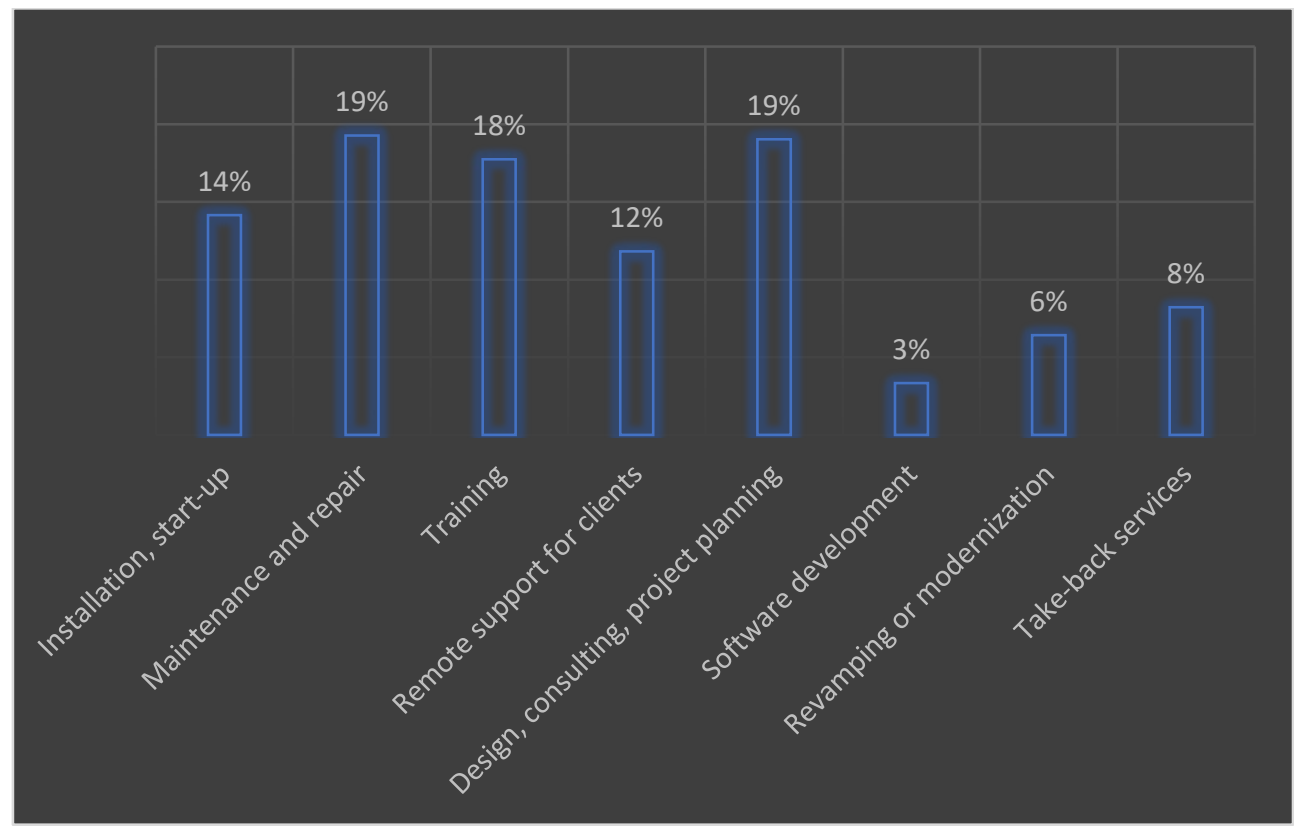

Figure 2 - Share of product-related services in manufacturing industry of Serbia

Results presented that Maintance and repair and Design, consulting, project planing are the most used PRS in manufacturing sector of Serbia. They are followed by Traning, Installation, start-up and Remote support for clients, other PRS are under $10 \%$ in the share of total sample.

\section{CONCLUSION}

Paper evaluates the use of PRS in manufacturing firms in Serbia. Findings contribute to the existing literature by presenting the position of PRS in manufacturing firms of transitional economies. The results showed that the Manufacture of other transport equipment used the most PRS per firm. Moreover, the results showed that Maintenance and repair and Design, consulting, project planning are the most used PRS in Serbian manufacturing firms. This research is limited only to the in-dept descriptive statistic, with some advanced analyes can see the impact of PRS on the manufacturing firms' performance. Future research should take into consideration different data sets from developed and transitional economies to compare it. Furthermore, this findings will help manufacturing firms in transitional economies for the successful transformation of product-oriented firms towards serviceoriented firms. 
Slavko Rakic - The role of product-related services in Serbian manufacturing industry

\section{REFERENCES}

[1] S. Vandermerwe and J. Rada, "Servitization of Business: Adding Value by Adding Services,” Eur. Manag. J., vol. 6, no. 4, 1988.

[2] L. Probst, L. Frideres, B. Cambier, J. Ankeraa, and S. Lidé, "Servitisation: Service and predictive maintenance contracts,” 2016.

[3] T. Baines et al., "Towards an Operations Strategy for Product-centric Servitization,” Int. J. Oper. Prod. Manag., vol. 29, no. 5, pp. 494-519, 2009.

[4] M. Szwejczewski, K. Goffin, and Z. Anagnostopoulos, "Product service systems , after-sales service and new product development,” Int. J. Prod. Res., no. May, pp. 37-41, 2015.

[5] A. Tukker, "Eight types of product-service system: eight ways to sustainability? Experiences from SusProNet,” Bus. Strateg. Environ., vol. 13, no. 4, pp. 246-260, 2004.

[6] U. Marjanovic, B. Lalic, V. Majstorovic, N. Medic, J. Prester, and I. Palcic, "How to increase share of product-related services in revenue? Strategy towards servitization,” in IFIP Advances in Information and Communication Technology, 2018.

[7] L. Faria Almeida and P. Cauchick Miguel, "Product-related services and the product development process - A preliminary analysis and research project outline,” in POMS 20th Annual Conference, 2009.

[8] M. Crozet and E. Milet, "Should everybody be in services? The effect of servitization on manufacturing firm performance,” J. Econ. Manag. Strateg., 2017.

[9] H. Gebauer, R. Krempl, E. Fleisch, and T. Friedli, "Innovation of product-related services," Manag. Serv. Qual., 2008.

[10] T. Baines and Victor Guang Shi, “A Delphi study to explore the adoption of servitization in UK companies,” Prod. Plan. Control, vol. 26, no. 14-15, pp. 1171-1187., 2015.

[11] A. Eggert, J. Hogreve, W. Ulaga, and E. Muenkhoff, "Revenue and Profit Implications of Industrial Service Strategies,” J. Serv. Res., vol. 17, no. 1, pp. 23-39, 2014.

[12] I. Visnjic Kastalli and B. Van Looy, "Servitization: Disentangling the impact of service business model innovation on manufacturing firm performance,” J. Oper. Manag., vol. 31, no. 4, pp. 169-180, 2013. 